\title{
Üçüncü Yerler Olarak Kafeler ve Gençlik: Balıkesir Örnek Olay İncelemesi
}

Youth and Cafés as Third Places: A Case Study in Balıkesir

\author{
Fahri Çakı \\ Betül Kızlltepe
}

\section{$\ddot{O} \mathbf{z}$}

Bu makalede; kafeler üçüncü yerler, sosyal ve sembolik sermayenin temel tartışmaları bağlamında ele alınacaktır. Araştırma, toplumsal değişimlerle üçüncü yerlerde sosyal ve sembolik sermaye ve mekânsal ayrışma arasındaki karşılıklı ilişkiyi kafeler olgusu içinde incelemeyi amaçlamaktadır. Makale kapsamındaki araştırma, Balıkesir/ Altıeylül ve Karesi ilçelerindeki kafeler üzerine inşa edilmiş, 18 kafede 40 gözlem yapılmış ve 40 kişi ile mülakat gerçekleştirilmiştir. Makale kafedeki eylemler ve anlamlar bağlamında lise ve üniversite öğrencileri arasında bir karşılaştırma yapmayı amaçlamaktadır. Makalede, internetin ve sosyal medyanın hayatın her alanına yayılmasıyla bireylerin pratiklerini ve algılarını değiştirdikleri incelenecek ve kafelerin zevk ve beğeni ayrımı ile desteklenen sembolik sermayenin mekânsal ayrışmanın temelini oluşturduğu tartışılacaktır.

Anahtar Kelimeler: Üçüncü Yerler, Sosyal ve Sembolik Sermaye, Kafeler, Mekânsal Ayrışma, Gençlik, Balıkesir.

Bu makale Betül Kızıltepe'nin Balıkesir Üniversitesi Sosyal Bilimler Enstitüsü Sosyoloji Anabilim Dalı'nda hazırlamış olduğu “Üçüncü Yerler ve Gençlik: Balıkesir'de Kafeler Örnek Olay İncelemesi” isimli yükssek lisans tezinden üretilmiştir ve BAP tarafından 2015/150 nolu proje ile desteklenmiştir.

Doç. Dr., Balıkesir Üniversitesi, Fen Edebiyat Fakültesi, Sosyoloji Bölümü, cakifahri@yahoo.com

Arş. Gör., Balıkesir Üniversitesi, Fen Edebiyat Fakültesi, Sosyoloji Bölümü, betulkiziltepe@balikesir.edu.tr

Bu makale iThenticate sistemi tarafından taranmıştır.

Makale Gönderim Tarihi: 26.08.2016

DOI: 10.17550/akademikincelemeler.308922 


\begin{abstract}
This paper examines cafés in terms of third places and in the context of main arguments of social-symbolic capital. It shows that third places change through social change and the mutual relationship between social-symbolic capital and spatial disintegration regarding cafés. It is conducted on young people who go to cafés in Altıeylül and Karesi districts of Balıkesir, 40 observations from 18 cafés are made and 40 participants are contacted to participate. The paper aims at comparing the two groups (high school and university students) in terms of their experiences and perceptions in regards to cafes. The paper demonstrates that the internet gained importance in third places and change person's experiences and perceptions. It also indicates that the cafés have become indicators of symbolic capital which makes use of distinction of pleasure and finally resulted in spatial disintegration.
\end{abstract}

Keywords: Third Places, Social and Symbolic Capital, Cafés, Spatial Disintegration, Youth, Balıkesir. 


\section{Giriş}

Gün geçtikçe değişen kentler farklı işlevleri ve anlamları barındıran kamusal alanlara ev sahipliği yapmaktadır. Bugün bireylerin birbirleri ile iletişimini sağlayan kamusal alanın bir parçası olan, ev ve iş yerleri dışında kalan ve insanların buluşma, sosyalleşme, eğlenme gibi amaçlarla kullandıkları yerler olarak tanımlanan üçüncü yerler, kentsel alanda meydana gelen farklılaşmaların ve oluşacak değişimlerin ipuçlarını vermektedirler. Kentteki değişimlerin daha önce ele alınmayan ve üçüncü yerlerden biri olan kafelerde incelenmesi sosyoloji disiplinine mekânsallığın farklı gruplar bağlamında hangi işlevsel ve anlamsal farklılıklara yol açtığını analiz etmek için katkı sağlayacaktır. Gençlerin aktif olarak kullandıkları bu yerler, onların mekânı hangi işlevlerde ve anlamlarda kullandıklarını anlamamızı sağlarken gençlerin değişen dünyalarını yansıtmaktadır. Sosyal medya ve internetin de etkisi ile üçüncü yerlerin farklı alanlara dönüşmesi ve kafelerin araştırılması bu noktadan hareketle ortaya çıkmış, olumlu özellikleri ile ele alınan bu yerlerin aynı zamanda potansiyel tehditlere de ev sahipliği yapabileceğini düşündürmeyi amaçlamaktadır. Bu bağlamda makalenin üzerinde odaklanacağı ana araştırma soruları şunlardır: Üçüncü yerlerin gençlerin yaşamında nasıl bir yeri, rolü ve anlamı vardır? Sosyal ve sembolik sermaye boyutuyla birlikte kafeler örneğinde mekânsal ayrışma kimliği ne şekilde inşa etmekte ve dönüştürmektedir? Bu maksada uygun olarak önce "üçünü yerler" ve "kafe" kavramlarına yönelik teorik yaklaşımlar incelenecek, yöntemsel yaklaşım betimlenecek ve daha sonra alan araştırmasından elde edilen bulgular sunulacaktır.

\section{Gündelik Yaşamın Sosyal Durakları: Üçüncü Yerler}

Üçüncü yerler kavramı, Ray Oldenburg'un 1989 yılında yayımlanan 'The Great Good Place' adlı kitabıyla sosyal bilimcilerin ilgisini çeken bir kavram haline gelmiştir. Ona göre; üçüncü yerler, topluluk hayatının sabitleyicileridir ve gündelik yaşamda yaratıcı etkileşimleri mümkün kılarlar. Oldenburg, üçüncü yerleri ev ve iş yerleri dışında kalan ve insanların buluşma, sosyalleşme, eğlenme gibi amaçlarla kullandıkları yerler olarak tanımlar. Üçüncü yerler nötr, eşitlikçi, temel aktivitesi sohbet olan, herkesin kolaylıkla ulaşabildiği, müdavimleri olan, sade bir profili ve neşeli ruh halini içeren, evden uzak ama ev gibi olan 
yerlerdir (Oldenburg, 1991: 20-42). Bu kapsamda; kahvehaneler, restoranlar, kulüpler, alışveriş-merkezleri, sinema ve tiyatrolar, kafeler, spor merkezleri, kütüphaneler vb. birçok yer üçüncü yerlere örnektir. Ancak bu yerlerin kullanım amaçları ve biçimleri birbirinden farklı olduğu gibi müdavimleri de farklılık gösterebilmekte ve üçüncü yerlerin kullanıcıları (müssterileri) yaş, cinsiyet, sınıfsal ve kültürel aidiyet eğilimleri bakımından farklılaşabilmektedir.

Oldenburg'un üçüncü yerler kavramı, bireylerin hayatlarında bir kaçış yeri olarak tanımlanan ve gündelik yaşamlarında tercih ettikleri önemli yerlerdir. Oldenburg'a göre üçüncü yerler birbirinden farklı sekiz özelliğe sahiptir (1991: 20-42). Ona göre; bireyler birbirlerine karşı koruma kalkanlarını harekete geçirmedikleri takdirde sosyalleşebilirler. Bu yüzden üçüncü yerler, ilk olarak nötr alanlardır ve nötr oldukları için de herkesin sosyalleşebileceği yerlerdir. Bu yerlerin nötr olması ile bağlantılı bir özelliği de eşitlikçi yerler oluşlarıdır; çünkü kimseyi dışlamazlar ve kapsayıcı niteliktedirler. Herkesin ulaşabildiği, resmiyetin ve dışlamanın olmadığ 1 bu yerler tüm statülere açıktır ve insanların bir araya gelirken eğlenceden başka bir amaçları yoktur (1991: 25). Bu yüzden üçüncü yerlerde saf bir sosyalleşme söz konusudur ve sohbet, üçüncü yerlerin olmazsa olmazıdır (1991: 26).

Oldenburg için üçüncü yerler kolayca ulaşılabilen ve bireylerin yalnız dahi gitseler bir tanıdığa rast gelebilecekleri yerlerdir. Uzun saatler açık kalabilen bu yerler için, açık olduğu saatler kadar bulundukları yer de önemlidir. Ulaşımı kolay olan üçüncü yerler, daha verimli hale gelir ve kentsel alanda verimli hale gelen üçüncü yerler, insanların sosyal kabiliyetlerini artırırlar (Oldenburg, 1991: 32). Ayrıca Oldenburg için üçüncü yerlerin cazibesi oturma kapasitesine, içecek çeşitlerine, park etme imkânına ve ücretine göre de değişir. Bu özellikler ziyaretçilerin dikkatini çektiği vakit, ziyaretçiler üçüncü yerin müdavimi olurlar. Zira müdavimlerin fazla olması üçüncü yerin canlılığını artırmaktadır (Oldenburg, 1991: 34).

Sadeliği ve gösterişsizliği barındıran bu yerler düşük profile sahiptirler. Oldenburg'a göre; düşük profiliyle üçüncü yerler, üst sınıftan yabancıların beklentilerini karşılamayan yerlerdir, sadeliği ve gösterişsiz dekoru sosyal bahaneleri azalttığı için bireylerin günlük rutinlerin- 
de yer alırlar (1991: 36-37). Bunların dışında üçüncü yerler, neşeli bir ruh haline sahiptir (Oldenburg, 1991: 37). Ciddi konuşmaların süresi uzun olmaz, endişe ve resmiyet hüküm sürmez ve bu yerlerin temeli gülme ve eğlencedir. Böylece bu yerlere geliş tekrarlanır. Son olarak, üçüncü yerler ev ortamı gibi bir ortama sahip olması sebebiyle ev tanımından çok da uzak olmayan bir özelliğe sahiptir. Üçüncü yerlerin eve benzeyen bu hali farklı bir içeriği barındırır; çünkü ev özel alan, üçüncü yerler ise kamusal alandır. Ev aktivite çeşitliliğini simgelerken üçüncü yerler sınırlı bir aktivite çeşitliliğini simgelemektedir. Bu yüzden Oldenburg'a göre üçüncü yerler ev değildir; fakat karşılaştırma yapılacak kadar da benzerliğe sahip olduğu açıktır (1991: 39).

Üçüncü yerleri tanımlayan bir başka teorisyen Christian Mikunda'dır. Oldenburg, üçüncü yerlerin ticari olma niteliğinden uzak kamusal alanlar olduğunu dile getirirken Mikunda üçüncü yerlerin ticari oluşunun özellikle altını çizer (Crick, 2011: 2). Öte taraftan, Oldenburg üçüncü yerlerdeki sadeliği ön plana çıkarırken Mikunda üçüncü yerlerin dikkat çeken görselliğini ele alır (Crick, 2011: 2). Oldenburg göre üçüncü yerlerin sadeliği bir avantajdır; çünkü bireyin kendi halini düşünmesini ve gösterişi azaltır; fakat Mikunda üçüncü yerlerin insanların yaşam tarzlarını yeniden yükleyebilmelerine imkân sağlayan yerler olabildiğini öne sürer (Crick, 2011: 3). Oldenburg'un tanımladığı bu içerik, eski zamanların üçüncü yerlerine daha yakınken Mikunda'nın yapmış olduğu tanım günümüz üçüncü yerlerinin içeriğine daha yakındır.

Üçüncü yerler kavramında ortak kanı, kişisel deneyime özgü yerler olduğudur. Bireyler, tercih ettikleri üçüncü yerler ile yer deneyimi kazanırken yere olan bağl1lı̆̆ da beraberinde getirir. Böylece, "yerler bizi dünyaya, tarihimize, hafizamıza, ailemize ve toplumumuza bağlar. İnsanlar ve yerler arasındaki ilişki geliştiğinde ortaya çıkan şey yer bağl1lığı duygusudur. Yer bağ l1lığı insanların kültürel, duygusal paylaşımları ile şekillenen sembolik bir ilişkidir" (Waxman, 2006: 37). Yer bağlılığ1 duygu, bilgi, inançlar, davranışlar ile karşılıklı iletişime sahiptir. Tuan'ın da belirttiği üzere bir yerin öncelikli işlevi, ait olma ve bağl1lık duygusu yaratmaktır (Waxman, 2006: 37). Üçüncü yerin kullanımında devamlılığı getiren yer bağlılı̆̆ının ise dört farklı boyutu 
vardır (Rosenbaum, Sweeney and Windhorst, 2009: 42). İlki, yer bağl1lığıdır ve bir kişinin ihtiyaçlarını karşılayan yer manasındadır. İkincisi, yer kimliğidir ve özel yer ile kişinin kimliği arasında bir uyum söz konusudur. Üçüncüsü, kuruluşsal vaattir ve bu vaat kişi ile yer arasında oluşan birlik duygusunu kapsar. Dördüncüsü ise yerin sahip olduğu yaşam tarzıdır ve kişinin günlük yaşam rutinini içerir. Bu da mekânda kalıcı müşteri olmayı yani müdavim olmayı ve yerin devamlı tercih edilmesini sağlar.

Diğer taraftan, internetin ve medyanın gündelik yaşamda güçlü bir yer edinmesi, üçüncü yerlere özgü faaliyetlerin bu alanlara taşınması sonucunu doğurmuş ve artık geleneksel üçüncü yerlere ek olarak farklı niteliklere sahip yerlerden de bahsedilebilir hale gelinmiştir. $\mathrm{Bu}$ bağlamda, Oldenburg'un sözünü etmediği üçüncü yerler ortaya çıkmıştır. Bunlar; ticari üçüncü yerler (Starbucks vb. yerler) insanların eğlendiği, siber âlemde birbirleri ile iletişim haline geçtikleri sanal üçüncü yerler (Facebook vb.) ve üçüncü yerlerin birden fazlasını içeren melez özellikteki üçüncü yerlerdir. Bu yerlerin her biri de farklı ihtiyaçlara ve tercihlere sahiptirler (Crick, 2011: 2).

Bugün teknolojinin ve sosyal medyanın gelişmesi ile üçüncü yerler Oldenburg'un tanımı içinde kalmamış ve değişime uğramıştır. İletişim kurmanın yolları değişmiş; fakat iletişim azalmamıştır. Kullanılan üçüncü yerler, kişisel deneyim içerirken tercih edilen üçüncü yerler, bireylerin kim olduğunu ve ne yaptıklarını tanımlar ve buna dair ipuçları verir hale gelmiştir. Nitekim üçüncü yerler görünürde herkese açık olan; ama gelir ve statüye göre bazı engellere takılabilen yerlere dönüşmüştür. Ayrıca çağdaş dünyada gençliğin sanal yerlerde çokça zaman geçirdiği, bu yerlerde kendilerine bir kimlik inşa ettikleri ve dünyaya bu yerlerin pencerelerinden baktıkları yadsınamaz bir gerçektir. Ancak gençliğin hala geleneksel üçüncü yerlerde -özellikle kafelerde- de önemli miktarda zaman geçirdikleri, kafe vb. yerlerde 'takıldıkları' ve buralarda da ciddi sosyal etkileşimler yaşadıkları ve gündelik yaşamlarının önemli bir kısmını buralarda geçirdikleri de kabul edilmelidir. Bu sebepledir ki gençlerin sanal yerlerdeki varlıkları kadar geleneksel üçüncü yerlerdeki varlıkları da sosyal ağ bağlantıları ve sermaye kapsamında araştırılmayı gerektirmektedir. 


\section{Bir Üçüncü Yer Örneği Olarak Kafeler}

Kafe kelimesi yabancı kökenli bir kelime olup Türk Dil Kurumu'nun sözlüğünde "içecek ve hafif yiyeceklerin satıldığı, bazılarında kapı önlerinde oturacak yerlerin bulunduğu ayaküstü yiyecek yerleri" olarak tanımlanmıştır. Genel tanımın yanı sıra kafe olarak addedilen mekânların içerikleri ülkeden ülkeye, kültürden kültüre değişiklik göstermektedir. Sosyalleşme olgusunun gerçekleştiği mekânlar topluma, coğrafyaya ve kültüre göre farklılıklar gösterirken bu niteliklere göre değişen içme davranışları, sosyalleşme mekânlarının oluşumunda da etkili olmaktadır (Çağlayan, 2012: 96). Eğlence ve sosyalleşme yerleri haline gelen mekânlar, toplumsal ilişkilerin devamlı dönüştüğü mekânlar olarak karşımıza çıkmaktadır.

Türk kültüründeki sosyalleşme mekânlarına bakıldığında, kafe kültürünün kahvehane kültüründen türediği söylenmektedir. Kafe, ülke genelinde kahvehanenin daha modern bir hali olup tek cinsiyet içermeyen bir mekândır. Her ne kadar kafeler ve kahvehaneler benzer işlevselliğe sahip olsalar da kafelerin ve kahvehanelerin müdavimleri farklı niteliklerdedir. "Kahvehanelerin özellikle erkeklerin vakit geçirdikleri, esnaf ve emeklilerin sıkça uğradıkları yerler, bunun aksine kafelerin ise her iki cinsiyet grubu tarafından tercih edilen ve daha çok gençler tarafindan tercih edilen mekânlar oldukları dikkat çekmektedir" (Yağbasan ve Ustakara, 2008: 241). Kafeler, bireylerin yiyip içmelerini temel alan bir mekân olarak görünseler de temel bir ihtiyaç olan sosyalleşmeyi bünyesinde barındırırlar. Kafe, bireylerin birbirleri ile görüştükleri ve etkileşim halinde oldukları, sosyal birliktelikleri sağlayan mekânsal bir araçtır. Türkiye'de kafe kültürü, genel anlamda kahvehane kültürü ile karşılaştırması yapılmak için kahvehane araştırmalarına dâhil edilmiş; kafeler özellikle araştırılan ve sosyolojik boyutuyla üzerinde durulan bir konu olmamıştır. Bu araştırmanın özgün amacı, kamusal alan ve üçüncü yerlerin önemli bir parçası olan kafelerin gençlik açısından gündelik hayatta nerede durduğunu, bu alanlarda zamanın nasıl kullanıldığını ve sosyal ve sembolik bağlamda ne tür sermayesel aktivitelere sahne olduğunu incelemektir.

1 TDK, Güncel Türkçe Sözlük. 
Kafe kültürünün kahvehane kültürünün yerine ülke genelinde yayılmasının en önemli nedeni 1970'lerden itibaren toplumsal yapıda genç nüfusun yarattığ 1 değişimdir; çünkü genç nüfusun artış1 ile gençlerin kamusal mekânlardaki müdavimliği de artış göstermiştir (Sami, 2010: 164). Yeni bir kültürel akımı getiren kafeler, kadın ve erkeğe birlikte sosyalleşebilme imkânını sağlamıştır. "Yeni kurulan şehir merkezlerinde ya da mahallelerin nirengi noktalarında kurulmuş bu mekânlar; insanların rahatça girip çıkmasını sağlayarak, cinsiyet ve yaş engelini ortadan kaldırmıştır" (Sami, 2010: 171). Kafeler bir taraftan herkesin rahatça girip çıkabilmesini sağlarken diğer taraftan da sosyal tabakalaşmayı barındıran mekânlar olmuştur. Kafelerin sahip olduğu modernlik imgesi (mekân tasarımı, ürün çeşitliliği gibi) beraberinde markalaşma ve tüketim kültürünü getirmiştir ve bunun bir sonucu olarak kafeler, tabakalı toplumsal yapının yeni simgesel göstergeleri olmuştur (Çağlayan, 2012: 109). Mekâna gitmek, ürünleri tüketmekten öte mekânın tüketilmesini içerir hale gelmiştir. Nitekim "toplumsal gösterimde sınıflararası tabakalaşmayı belirgin bir şekilde ortaya çıkaran kafeler; kendilerine özgü bir müşteri görünüşü yaratırken, sınıflararası statü ayrımını da beraberinde getirmiştir" (Sami, 2010: 170). Bu bağlamda gidilen mekânlar sembolik bir değere dönüşmekte ve sembolik sermayeye hizmet etmektedir. Bourdieu'nün de belirttiği üzere sembolik sermaye bütün sermayelerde görülebilecek, bireyin sahip olduğu toplumsal ağlar ile desteklenen ve ekonomik olarak görünebilen sermayedir (Bourdieu, 2007). Örneğin; bireylerin kentsel alanda ayrışması, bir kesimin bir alana girebilirken diğerlerinin girememesi sembolik sermayenin bir tezahürüdür. Toplumsal tabakalaşmanın ve mekânsal ayrışmanın temelinde sembolik sermaye yatmaktadır. Statüsünü korumaya ve kendi farklılığını vurgulamaya çal1şan bireyler, sembolik bir strateji sergilerler. Böylelikle ekonomik anlamda sembolik olabilecek mekânı tüketmeyi tercih ederler. Başka bir deyişle, statüyü yansıtan zevk ve beğeniler özel mekânların tüketilmesi ile somutlaşmaktadır. Bu noktada da Bourdieu'nün 'habitus' kavramı devreye girer. Bourdieu'nün analizinde bireyin sahip olduğu sermaye onun habitusunu belirleyerek bireyin ayrılmaz bir parçası haline gelir. Kültürel sembollerin farklılığı olan 'habitus', bireyin değerlerini ve düşünce biçimini şekillendirir. Bireylerin ve grupların gündelik yaşam 
pratikleri, alışkanlıkları, beğenileri, konuşma biçimi, gittikleri yerler ise bu sermaye dâhilindedir.

Kamusal bir mekân olan kafelerin, yaşanılan alanlarda ürettiği mekânsal etkinliklerinin çözümlenmesi toplumsal tabakalaşma hakkında fikir sahibi olmayı sağlamaktadır. Bu bağlamda kafeler; müdavimlere fiziksel özellikleri ve bulunduğu çevre bakımından önemli bir çeşitlilik sunmakta ve bu çeşitliliğin içeriği onların sosyal yaşama nasıl etki ettiklerini ortaya çıkarmaktadır. Örneğin; kahvehane kültürünün incelendiği birçok araştırmada kahvehane kültüründe müdavimlerin önemli bir yer tuttuğu görülmüsstür. İlk başta belirli sınırlarda devam eden sohbetlerin mekânı olan kahvehane, "zamanla müdavimlerin özelliklerine göre, gündelik hayatı ve sosyal yaşamı derinden etkileyebilecek sohbetlerin, bilgi alışverişlerinin yapıldığı mekânlar olmuşlardır" (Ulusoy, 2011: 162). Aynı şekilde, kafe kültüründe de müdavimlerin sahip olduğu özellikler ve kafelerin gündelik hayattaki yerleri sosyal yaşamı etkileyebilecek niteliktedirler.

Kafeler ülkemizde kahvehaneler ile birlikte araştırılırken yurtdışında özel olarak ilgilenilen bir üçüncü yerdir. Üçüncü yerin nasıl kullanıldığı ve teknoloji ile hangi değişikliklere maruz kaldığı incelenen konulardır. Örneğin; bir araştırmada kafelerde insanların nasıl davrandıkları araştırılmış ve araştırmada bireylerin kafe içinde dışarıyı gözlemledikleri, sohbet ettikleri, internette bulanıklaşan sosyal alanın kafede belirginleştiği, bireylerin (hem yalnız hem de grup halinde gelenlerin) telefonla ilgilendikleri görülmüştür (Memarovic, Fels, Anacleto, Calderon, Gobbo and Carroll, 2013). Öte yandan kafelere de yayılan internet ağı, bu yerlerin kullanımında değişikliğe sebep olmuş ve wi-fi özelliği ile sosyal yaşamı büyük oranda etkilemiştir. Bu konuyla ilgili yapılan araştırmalara göre; kafeler üçe ayrılmaktadır: sosyal (iletişimin, sohbetin yoğun olduğu), çok işlevli (iletişim ve bireysel aktivitelerin olduğu, okuma, nette takılma gibi) ve sosyal olmayan (daha çok bireysel aktivitelerin yoğun olduğu, pc, tablet, gazete ve kitap ile olan uğraşlar) (Woldoff, Lozzi, and Dilks, 2013: 208). Kafelerdeki internet hizmeti kafelerin bu sebeple tercih edilmelerini de etkilemektedir. Kafeler sunduğu ücretsiz internet ile daha fazla yoğunlaşmakta ve bu durum kafelerde ne konuşulduğunu da etkilemektedir. Alicia Carr araştırmasında bireylerin en fazla konuştukları konunun, günlük ya- 
şam olduğunu gözlemlemiştir (2010). Kafeler, bireyler için kısa süreli de olsa hayattan kaçışı simgelemekte ve hayata ve insanlara uzaktan bakmayı sağlamaktadır.

Son zamanlarda hangi yaş grubunun hangi yerleri, hangi zaman diliminde kullandıkları akademisyenlerin incelemeye başladıkları yeni konular haline gelmiştir. Nitekim, bireylerin aktivitelerini gerçekleştirdikleri yerlerin içerikleri zamanla değiştiği gibi zamansal farklılıklarla aktiviteler de değişebilmektedir. Bireylerin bir yerde geçirdikleri zamanın artması, yere olan bağlılığını artırarak yeri sahiplenmelerini ve yerin müdavimi olmalarını sağlamaktadır. Böylece mekân ve mekâna dair aktiviteler bireylerin 'habituslarına' girmekte ve hangi zamanlarda hangi yerleri tercih ettikleri bireylerin gündelik yaşam kriterleri üzerine ipuçları vermektedir. Gündelik yaşamlarında mekâna anlam atfeden bireyler mekân kodlarını yerle bir etmekte ve onu yeniden kurmaktadırlar. Bugün özellikle gençler tarafindan yoğun bir sosyalleşme alanı olarak kullanılan kafeler mekânın yeniden tanımlandığı toplumsal alanın yeni belirleyicileri olup farklı bir sosyal ortama sahiptir. Sosyal bütünleşmeyi sağlayan bu yerler, kültürel ve sosyal anlamda dönüşümün bir parçasıdır ve bireyler tercih ettikleri yerlerle sosyal ve kültürel sermayelerini sergilemektedirler.

\section{Araştırma Yöntemi}

Gençlerin gündelik yaşamında kafelerin işlevlerini incelemeyi amaçlayan bu araştırma nitel araştırma geleneği çerçevesinde inşa edilmiş olup etnografik, fenomenolojik bir yaklaşım ile gerçekleştirilmiştir. Buna uygun olarak araştırmada elde edilen veriler, yarı-yapılandırılmış gözlem ve görüşme formu kullanılarak toplanmıştır. Araştırmada, Balıkesir'in Altıeylül ve Karesi ilçelerinde yer alan ve müdavimleri çoğunlukla gençlerden oluşan 18 kafede 40 gözlem yapılmış, gözlem yapılan kafelerin içinden öğrenci nüfusu açısından diğerlerinden görece daha yoğun oldukları tespit edilen 12 kafe seçilmiş ve yaklaşı 20 ortaöğretim ve 20 yükseköğrenim genciyle mülakat yapılmıştır. Araştırma, Balıkesir ilinin Altıeylül ve Karesi ilçeleri ile sınırlandırılmıştır. Araştırmanın bu ilçeler ile sınırlandırılmasının sebebi ise Balıkesir Üniversitesi'nin merkez kampüsünün Altıeylül ilçesi sınırları içerisinde yer alması ve yoğun bir öğrenci nüfusunun bu bölgede ve hemen yakınındaki Karesi ilçesinde boş zamanlarını geçiriyor olmasıdır. 
Araştırmanın evrenini kafeleri kullanan gençler; örneklemini ise Altıeylül ve Karesi ilçeleri kapsamında bulunan kafelerde vakit geçiren gençler oluşturmaktadır. Araştırmada maksimum çeşitlilik örneklemi kullanılmıştır. Görüşmecilerden 20 genç lise öğrencisi iken 20 genç üniversite öğrencisidir. Lise öğrencilerinin 14'ü kız 6's1 erkek, üniversite öğrencilerinin 11'i kı 9'u erkek olmak üzere toplamda 25 kız 15 erkek öğrenci ile görüşülmüştür. Araştırmadan elde edilen veriler, çözümlemeleri yapıldıktan sonra nitel araştırma yöntemine uygun olarak Maxqda 12 programında kodlanmıştır. Kodlanan veriler belirli başlıklara ayrılmış ve görüşme ve gözlemlerin derinlemesine anlamlandırılması sağlanmıştır.

\section{Bulgular}

\section{Üçüncü Yerlerde Zaman ve Yer Kullanımı}

\section{Zaman Kavramı}

Gençler gündelik yaşamlarında zamanlarının önemli bir bölümünü geçirdikleri kafelerde sosyal bir zaman üretmekte ve ürettikleri bu zaman onların sosyal yaşantıları hakkında ipuçları vermektedir. Nitekim hangi kafeye gittikleri, orada ne kadar vakit geçirdikleri bu kapsamda ele alınması gereken konulardır. Araştırma verileri kafelere gitme sıklığı lise ve üniversite öğrencileri arasında farklılıklar göstermektedir. Üniversite öğrencilerinin lise öğrencilerine göre kafe tercihinde daha seçici oldukları gözlemlenmiştir. Lise öğrencilerinin çoğunlukla haftanın her gününde gittiği kafeler, üniversite öğrencilerinde en fazla haftada 3 gün olarak belirtilmiştir. 'Haftanın her günü' kafeye gittiğini söyleyen lise öğrencileri üniversite öğrencilerine göre oldukça fazladır. Bunun önemli etkenlerden biri lise öğrencilerinin görüşmeler esnasında sık sık dile getirdikleri 'kentte yapılacak başka bir faaliyetin olmaması' dır. Üniversite öğrencilerinin gerek üniversite içinde fazladan vakitlerinin olması gerek yurt/öğrenci evlerinde başka aktiviteler yapabilme şansı varken lise öğrencilerinin sadece kafe gibi bir üçüncü yerde uzun süre oturma, bir şeyler yapabilme ve sosyalleşebilme şansları vardır. Başka bir deyişle; lise öğrencileri açısından kafeler dışında uzun süreli sosyalleşilebilecek başka bir yer bulunmamaktadır. Bu yüzden 'haftada en fazla 2 gün' kafeye gittiğini söyleyen üniversite öğrencileri araştırmada daha fazla yer almıştır. Ayrıca üniversite öğrencilerinde il dışın- 
da okumanın getirmiş olduğu harçlık yetiştirememe durumu kafelere daha az gitmeye sebep olmaktadir.

Lise ve üniversite öğrencilerinin kafeye gitme sıklığındaki farkl111k kafeye gidilen saatlerde de kendini göstermektedir. Üniversite öğrencisinin zamanı kullanma kültürü ile lise öğrencisinin zamanı kullanma kültürü farklıdır. Lise öğrencilerinin okul saatlerinin belli olmas1 ve ebeveynleri tarafından kontrol edilmesi, onların sadece okul çıkış saatlerinde sinırlı zaman diliminde kafede vakit geçirmelerine sebep olmaktadır. Öte yandan üniversite öğrencilerinin kafeye gitmeyi tercih ettiği saatler lise öğrencilerine göre günün ileri saatlerini kapsamaktadır. Öğrencilerin hem akşam saatlerinde okul programlarının bitmesi hem de ailelerinden ayrı bir şehirde yaşamanın getirdiği giriş çıkışlarının tam manası ile kontrol edilmemesi kafelere gidiş saatlerini de günün ileri saatlerine itmektedir. Bu da gösteriyor ki gün içerisinde kafenin kullanım zamanlarında profil açısından bir ayrışma söz konusudur.

Bunların yanı sıra üniversite ve lise öğrencilerinin gün içinde farklı saatlerde gerçekleştirdikleri kafeye gidiş saatleri, kafede geçirilen zaman diliminde değişiklik göstermektedir. Lise öğrencilerinin kafede geçirdikleri zamanın üniversite öğrencilerine oranla oldukça fazla olduğu görülmüştür. Bununla ilişkili olarak kafede geçirilen zaman, lise öğrencilerinde uzun ve niteliksiz bir hale dönüşmektedir. Öğrencilerin bir kafede iki saat geçirdikten sonra kafe değiştirerek aynı süreyi başka bir kafede daha geçirmeleri söz konusudur. Örneğin; bir öğrenci bu konuda bir kafede en fazla iki saat harcadığını ve ardından da başka bir kafeye giderek toplamda 4 saatini kafede geçirdiğini (Görüşmeci 1, lise öğrencisi, erkek) dile getirmiştir. Aktarılan bu ifade, lise öğrencilerinin kentte yapacakları tek aktivite olarak gözüken kafede zaman geçirmeye ayırdıkları zamanın verimsiz ve boşa geçtiğini göstermektedir. Üniversite öğrencilerinin geçirdikleri vakit ise gündelik yaşamda mola vermeye daha yatkındır; öğrencilerin genellikle dile getirdikleri şey 'bir şeyleri içecek kadar oturmak’tır. Kafe, gün içerisinde lise öğrencileri için bir amaçken üniversite öğrencileri için bir araç niteliğindedir ve kafede geçirdikleri zaman bunun önemli bir göstergesidir.

\section{Kullanım Amacı}

Kafe, sosyalleşme odaklı üçüncü yerlerden biridir ve sohbet temelli bir yer olarak karşımıza çıkmaktadır. Fakat günümüz toplumunda mey- 
dana gelen değişimler kafenin içeriğini de değiştirmeye başlamış ve gözlemler sırasında gençlerin kafede sohbetten ziyade telefonlarla ilgilendikleri görülmüştür. Ayrıca gençlerin kafeyi kullanım amaçları lise ve üniversite öğrencilerine göre değişiklik göstermektedir.

Kafelerin temel işlevlerinden biri olan 'atıştırma', kafenin hangi amaçla kullanıldığı lise öğrencilerinin cevaplarında en son amacı sergilerken üniversite öğrencilerinin cevaplarında yer dahi alamamıştır. Bu da kafenin görünürde bir atıştırma yeri olduğunu ama sosyal hayatta bu anlamı yüzeysel olarak içerdiğini ve sosyal bir anlama dönüştüğünü göstermektedir. Cevapların yoğunlaştığ ' 'arkadaşlarla birlikte olmak', 'sohbet' ve 'vakit öldürmek' başlıkları liseli gençlerin kafeleri ne için kullandığını gözler önüne sermektedir. Bu nedenle denilebilecek şey; lise öğrencilerinin kafeleri yalnızken değil grup halinde kullanmayı tercih ettikleridir. Kafenin zaman öldürmek ve sadece bir şeyleri geçiştirmek için kullanılıyor olması liseli gençler örnekleminde önemli bir yere sahiptir. Lise öğrencilerinin kafeyi vakit öldürmek için tercih etmelerinin en önemli sebebi, kendilerinin görüşmeler sırasında da sık sık dile getirdikleri gibi Balıkesir'de başka bir faaliyetin olmamasıdır. $\mathrm{Bu}$ anlamda kafeye gitme eylemi, lise öğrencileri arasında vakit geçirebilecek ve niteliği olmayan bir aktivite olarak karşımıza çıkmaktadır.

Kafenin hangi amaçla kullanıldığı sorusuna üniversite öğrencilerinin vermiş olduğu cevaplarda ise sohbet temel amacı oluşturmaktadır ve kafe bu kelime ile eşleştirilmektedir. Lise öğrencilerinde birliktelik anlayışı ön planda olup nitelikli bir içerik yer almazken, üniversite öğrencilerinde sadece birliktelik değil nitelikli bir içerik olan muhabbet de kafenin içeriğine eşlik etmektedir. Üniversite öğrencilerinin sohbete bu denli önem vermeleri, kafede edilen muhabbetin kendilerini rahatlatmasının yanı sıra gündelik yaşamda kafeyi bir 'mola' gibi gördüklerini göstermektedir. Nitekim kafelerde, lise öğrencilerinde telefon kullanımının, üniversite öğrencilerinde ise hararetli konuşmaların yaygın olduğu gözlemlenmiştir. Bu da lise öğrencilerinin aksine üniversite öğrencilerinin kafeyi zaman geçirmek amacıyla kullanmadıklarını göstermektedir.

Gençlerin kafeleri hangi amaçla kullandıkları kadar gidecekleri kafelerin hangi özelliklere sahip olması gerektiği de toplumsal ipuçları verebilmektedir. Veriler 1şı̆̆ında; gençlerin kafelerde bulunmasını is- 
tedikleri nitelikler, öğrenci kategorilerine göre farklı cevap kümelerini içermektedir. Lise öğrencileriyle yapılan görüşmelerde talepler; kafe ortamının iyi olması, kafeyi tercih eden bireylerin 'düzgün' olması ve internet erişimi üzerinde yoğunlaşmaktadır. Kafe ortamının iyi olmas1, öğrenciler için garsonların başlarına gelmediği, saatlerce rahat rahat oturdukları ya da sosyal ortamın iyi olduğu gibi farklı anlamlara sahiptir. Öte yandan, Oldenburg üçüncü yerleri kimseyi dışlamayan kapsayıcı yerler olarak tanımlamasına rağmen soruyla ilgili lise öğrencilerinin vermiş olduğu cevaplarda kafe dışlayıcı bir içeriğe sahiptir. Lise öğrencilerinin talepler konusunda üzerinde durduğu nitelik kafeye gelenlerle ilgilidir. $\mathrm{Bu}$ nitelik ise dış görünüşlerinin iyi olmasını kapsamakta ve öğrencilerde etiketleme/dışlama pratiğinin yaygın olduğunu göstermektedir. Örneğin; bir lise öğrencisi "Kafeye düzgün olanlar gelmeli, düzgün derken dışarıdan düzgün görünen tiplerin gelmesi gerekiyor..." (Görüşmeci 15, lise öğrencisi, kız) ifadeleri ile tercih ettiği kafeye gelebilecek profili sunmuş ve kamusal bir alana 'düzgün' insanların gelmesi gerektiğini vurgulamıştır. Bir başka öğrenci ise "Yaşlıların gelmediği bi yer olmalı, hep gençlerin, genç yakışıklıların olduğu bi yer olmalı" (Görüşmeci 11, lise öğrencisi, kız) ifadelerini kullanırken kafeye gelmesi gereken birey profilini yaş kriteri üzerinden tanımlamıştır. Tüm bu ifadelerde ortak olan, öğrencilerin kamusal alan olan bir yerde bir grubu ötekileştirerek dışlama pratiği sergilemeleridir. Kafeye gelecek insanların 'düzgün' olması, 'iyi' giyimli olması hatta sadece gençlerden ibaret olması gerektiği belirtilirken bu özelliklere sahip olmayan grup dışlanmaktadır. Bu bilgiler ekseninde, kafeler öğrenciler arasında gençlerin yeri/yaşlıların yeri olarak tanım farklılığını içermekte ve ötekileştirme pratiğine dair örnekler sunmaktadır.

Üniversite öğrencilerinin vurguladığ özellikler incelendiğinde ise lise öğrencilerinin net olmayan ve dışlayıcı ifadelerinin aksine daha özel nitelikler karşımıza çıkmaktadır. Lise öğrencilerinin bahsetmediği ucuz yer anlayışı üniversite öğrencilerinin üzerinde durduğu bir özelliktir; fakat kullanım amacına yönelik sorunun cevaplarında dikkat çeken bir diğer unsur da ucuz yer anlayışının aynı zamanda kaliteli de bir yer anlayışına sahip olması gerektiğidir. Üniversite öğrencileri arasında üzerinde durulan ikinci özellik ise kaliteli sosyal ortamdır. Öğrenciler için sohbet amaçlı kullandıkları kafede bunu rahatlıkla 
gerçekleştirebilecekleri ve onları rahatsız etmeyecek yerlerin olması önem arz etmektedir.

\section{Kafeden Beklentiler}

Araştırmada öğrencilere kafelerde olmasını istedikleri özelliklerin neler olduğu sorulduğunda; her iki öğrenci grubunda öncellikli tercihlerin benzer olduğu görülmektedir. Öğrencilerin birinci tercihi olan geniş kafelerin nedeni, merkezdeki kafelerin çoğunlukla küçük alanlara hapsolması ve basık yerler olmasıdır. Öğrencilerin ifadesiyle masaların dip dibe oluşu özel alanı sınırlandırmakta ve geniş kafe özel alan ile eşleştirilmektedir. Bir başka özellik, kafelerin oyun oynanacak yer şeklinde tanımlanması ile paralellik göstermektedir. Öğrenciler, kafelerdeki oyun seçeneğinin az olması (okey, tavla, kart, tabu) sebebiyle oyunların daha fazla olmasinı talep etmektedirler. Bu oyunların genel olarak langırt, bilardo gibi büyük alan gerektiren oyunlar olması ilk tercihle benzerlik göstermektedir. Ayrıca kafeyi ev dışında en fazla zaman geçirdikleri yer olarak tanımlayan lise öğrencilerinin oyun çokluğu tercihi, üniversite öğrencilerine göre daha fazladır. Kafelerde daha fazla zaman geçiren liseli gençlerin bu istekleri, geçirilen zaman dilimine göre oldukça anlamlıdır.

Araştırmada dikkat çeken bir diğer konu ise lise öğrencileri arasında kafelerin bir flört yeri olarak tanımlanmasıdır. Bu da üçüncü yerlerin sosyal yapıya göre anlam ve amaç değişikliğine uğradığını simgelemektedir. Bununla ilişkili olarak, lise öğrencilerinin elit ortam içeren kafelere ve kafeleri tercih edenlere dair talepleri de vardır. Böylelikle liseli gençler, kafedeki mekân tüketimini görünür kılmaktadırlar. Elit kafe, lise öğrencileri için modernlik simgesi şeklinde algılanmakta ve bu tarz kafelerin çoğalmasını bir statü göstergesi olarak talep etmektedirler. Başka bir deyişle; kafeler lise öğrencileri için kendilerini gösterebildikleri, marka değerine sahip yerlerde bulunarak statülerini sergileyebildikleri ve erkek/kız arkadaş edinebilecekleri bir yer olarak karşımıza çıkmaktadır. Kafeye gelen bireyler üzerinden talepler belirten lise öğrencilerinin tutumlarının aksine üniversite öğrencileri kafe personelinin nazik olması ile ilgilenmektedirler.

Gözden Irak Kafeler

Gözden ırak kafeler, konum olarak binaların en tepesinde yer alan ve 
içindekilerin etrafi görebildiği ama etraftakilerin kafedekileri görmelerinin zor olduğu kafelerdir. Gözden rrak kafeler, kentin merkezinde farklı yerlere yerleştirilmiş çeşitliliği bol kafelerdir. Gözlemlerin yapıldığı sırada bu tarz kafeler özellikle sevgililerin, tanıştırılmak amacıyla ve ileride çift olabilecek bireylerin bir araya geldikleri yerler olarak dikkat çekmiştir. Gözlemler sırasında gözden rrak kafeler; gençlerin sevgilileriyle daha rahat davrandıkları, başörtülü gençlerin başkalarının görmeyeceği bir yer olarak tanımlanması sebebiyle tercih ettikleri ve bir birlikteliğe başlamaları için arkadaşların tanıştırıldıkları yerler olarak gözlemlenmiştir. Bu gözlemler araştırmanın görüşme kısmı ile de desteklenmiş̧ir. Gençler dışarıdakilerin onları kolayca göremediği kafelere sevgilileri ile gittiklerini ve böyle yerlerde arkadaşlarının arac1 olduğu tanışmalar düzenlediklerini belirtmişlerdir.

Araştırmada katılımcıların hemcinsleri ile farklı, sevgilileri ile farklı yerlere gittikleri gözlemlenmiştir. Bir öğrenci, "Sevgilimle kolayca görünemeyeceğimiz yerlere giderim. Kimsenin rahatsız etmeyeceği rahat rahat oturabileceğimiz bir kafeye giderim. Ama erkek arkadaşlarla buluşunca oyunu fazla olan kafelere giderim, genelde kahveye giderim" (Görüşmeci 1, lise öğrencisi, erkek) ifadelerine yer verirken başka bir öğrenci ise "Kız arkadaşlarımla gittiğim kafeler, erkek arkadaşımla gittiğim kafelerden farklıdır, daha sıradandır. Erkek arkadaşımla daha şık, sessiz ve milletin bizi görüp rahatsız edemeyeceği yerlere giderim" (Görüşmeci 4, lise öğrencisi, kı) sözleri ile hem kız hem erkek öğrenciler için kafelerin hemcins ve sevgili ile gidilen kafeler olmak üzere ikiye ayrıldığına dikkat çekmektedir.

Araştırmada başörtülü gençlerin görece gözden rrak kafeleri tercih etmelerinin en önemli sebebi, birileri tarafından görülmeyi engellemektir. Üniversiteyi ailelerinin yanında okuyan ve şehrin içinde tanıdıklara, akrabalara denk gelmemek için bu tarz bir önlem aldıklarını belirten öğrencilerden biri şunları aktarmıştır: "Merkezde olup da kimsenin beni görmeyeceği yerler var burda. Öyle yerlere birilerinin beni görmesini istemeyeceğim zaman giderim. Yani eğer o biriyle görünmek istemiyorsam ya da ilk defa biriyle tanıştırıliyorsam bu tarz yerleri tercih ederim" (Görüşmeci 27, üniversite öğrencisi, kız).

Gözden 1rak olan kafelerin tercih edilmesindeki bir diğer sebep, ciddi konuların konuşulması ve bu konuşmaların herhangi biri tarafın- 
dan duyulmasını önlemektir. Özellikle üniversite öğrencileri arasında yaygın olan bu düşüncenin kaynağı özel görüşmelerdir. Araştırma s1rasında bir kızı bir erkekle/bir erkeği bir kızla tanıştırmak için arkadaş gruplarınca bir araya gelinen durumlar gözlemlenmiştir. Gençler, bir anlamda 'çöpçatanlığın' yapıldı ğı bu buluşmalarda belli bir süre yalnız bırakılıp sonra tekrar grup halinde toplanmaktadırlar. Gözden ırak olan bir kafede bu tarz eylemlerin gerçekleştirilmesi, bireylerin başkaları tarafından görülmesini ve durumun tanıdık/akrabalar tarafından negatif algılanmasını engellemek için olduğu belirtilmektedir. Öğrencilerden birinin de dile getirdiği üzere "Olmayacak biri ile görüşürken görünmek biraz kötü bir durum, hakkımda kötü düşünebilirler. Akrabalarım da var burda. Söylenti çıkabilir" (Görüşmeci 28, üniversite öğrencisi, kız) kafenin niteliği söylenti çıkmasını engelleyebilmektedir. Herkesin kolaylıkla görebileceği bir yerde bir erkekle/bir kızla buluşma ayarlamak tehlikeli bir eylem olarak görülebilmektedir.

Görüldüğü üzere gözden ırak olarak nitelendirilen kafelerde mekânın kodu değişmekte ve kafeye gelenlerin farklı eylemleri ile üçüncü yer farklı anlamları barındırmaya başlamaktadır. Bu tarz kafeler, gençlere eylemlerinde özgürlüğü getirdiği gibi bireylerin (özellikle ailelerinin yanında üniversitede okuyan gençlerin) 'el âlem ne der' düşüncesi içinde hareket ederek tanışmaları görünmeyecek bir yerde gerçekleştirdikleri yerlerdir. Gençler, kendi taktikleri ile kontrol mekanizmalarını savuşturmaktadırlar. Kentin büyükşehir olması fakat hala küçük şehir ilişki ağı olan cemaat ilişkisini ve kontrol mekanizmasını barındırması sebebiyle gençler (özellikle kadınlar) gözden ırak kafelerde görüşme ve tanışmalar düzenlemektedirler.

Internet Hizmeti ve Melezleşen Üçüncü Yer

Günümüzde teknolojinin hızla gelişmesi beraberinde gençlerin bu alanla daha fazla ilgilenmelerini getirmiştir. Nitekim teknolojik çağın içine doğan gençlerin teknoloji ile olan yakın ilişkisi, gündelik yaşamda da yer bulmaktadır. Son dönemlerde üçüncü yerlerde internet kullanımının yaygınlaşması ile bu yerleri tercih ederken internetin önemli olup olmadığını öğrenmek ve üçüncü yerlerin sanal dönüşümünü incelemek elzem hale gelmiştir. 
Araştırmada kafenin internete sahip olması gerektiğini düşünen öğrencilerin çoğunluğu oluşturması dikkat çekicidir. Teknolojik aletlerin yaygınlaşması, telefonlarda kullanılan uygulamaların internet gerektirmesi ve kafe işletmecilerinin müşteri kaybına engel olmaya çalışması, kafede internet hizmeti sunulmasını beraberinde getirmiştir. Öğrencilerin akıllı telefonlara sahip olmaları devamlı 'çevrimiçi' olmalarını gerektirmektedir. Konum bildirme, durum güncellemeleri ve konuşma/mesajlaşma uygulamaları ile öğrenciler kafelerdeki internete 'kafede olması gereken bir nitelik' olarak bakmaktadırlar. İnternet, bir öğrencinin dile getirdiği üzere "Artık kafede internetin bulunması kafede çay-kahve olması gibi bir şey. Nasıl çaysız kahvesiz kafe olmazsa internetsiz kafe de olmaz bence" (Görüşmeci 26, üniversite öğrencisi, erkek) kafedeki yiyecek içecek kadar önemli hale gelmiştir. Bir başka öğrenci de kafede internet olmasının artık bir ihtiyaç olduğunu şu sözlerle aktarmıştır: "Artık herkesin elinde akıllı telefonlar var. Eskisi gibi internetsiz kullanamıyorsun telefonu. Telefondaki her şey için internet şart ve artı internet önemli bir ihtiyaç" (Görüşmeci 25, üniversite öğrencisi, erkek).

Araştırmada internetin önemli olmasının yanı sıra, internet olduğu zaman gençlerin bunu yoğun bir şekilde kullandıkları da görülmüştür. İnternet paketinin sınırlı olması sebebiyle kafedeki interneti kullandığını söyleyen bir öğrenci, şu ifadelere yer vermiştir: "Kafede interneti yoğun kullanırım. Sonuçta ücretsiz. Paketim olsa bile ondan çıkıp wi-fiye geçerim. İnternet paketim 10 GB olsaydı kullanmazdım. O da ihtiyaç çünkü iletişim kurmam için gerekli” (Görüşmeci 37, üniversite öğrencisi, kız). Bir başka öğrencinin görüşlerini "İnterneti yoğun olarak kullanırım. Bedava sonuçta. Bi çay iç saatlerce nete gir. Bazen kafede sessizce oturup telefonla internetlik işlerimizi hallettiğimiz bile olur" (Görüşmeci 26, üniversite öğrencisi, erkek) şeklinde ifade edişinde görüldüğü gibi, kafede bir çay ile sınırsız olan internete girebilme hakk1 elde edilmektedir. Hatta bu sinırsız ve ucuz kullanım ile telefon kullanımı sohbetin önüne geçebilmektedir.

Anlaşıldığı üzere internetin ve sosyal medyanın gündelik yaşamda güçlü bir yer edinmesi sonucunda, üçüncü yerlerde önemli değişiklikler meydana gelmiş ve üçüncü yerlere özgü faaliyetlerin bu alanlara taşınması sonucunu doğurmuştur. Bugün kafeler Oldenburg'un sözünü 
etmediği melez bir üçüncü yer halini almaya başlamıştır. Kafe hem yüz yüze iletişime hem de sunduğu internet hizmeti ile bu alandan yürütülen bir iletişime ev sahipliği yapmaktadır. Diğer yandan, kafedeki internet hizmeti ile gündelik hayattaki sosyal yaşam yara almaya başlamıştır. Gençler yüz yüze iletişim kurmak yerine, karşılarında iletişim kurabilecekleri biri olmasına rağmen internet üzerinden gerçekleştirilen iletişime odaklanmaya başlamışlardır. Bunun sonucunda; katılımcıların da belirttiği üzere telefonların kullanımı kafe içinde artarken sosyal izolasyona yol açmakta ve sosyallik zayıflamaktadır. Başka bir deyişle, sosyal olmayan bir üçüncü yer ortaya çıkmaktadır.

\section{Sermaye Yansıması Olarak Kafe}

\section{"Kafe Seçimi Bireyi Tanımlar"}

Sermaye, Bourdieu'nün vurguladığı üzere sosyal ayrımın bir aracıdır. Bireylerin pratiklerine sinen bu sermaye; kültürel kodlar, grup aidiyetleri ile kendini göstermektedir. Bununla bağlantılı olarak bireylerin gün içinde yeme, içme ve giyinme gibi gündelik pratikleri, vakit geçirdikleri mekânlar, oturdukları yerler, gittikleri okullar gibi özellikler sosyal ve sembolik sermayelerin yansımasını oluşturmaktadırlar. Bugün gençlerin gündelik yaşamlarında önemli bir yere sahip olan kafeler, sermaye yansıması olarak da karşımıza çıkmaktadır.

Yapılan araştırmada katılımcıların gittikleri kafeleri önemli gördükleri ve kendilerine uygun kafelere, dışarıdan kendilerini tanımlayabilecek veya görünmek isteyecekleri kafelere gittikleri gözlemlenmiş; gidilen kafenin sosyal ve sembolik sermaye ile ilişkili olduğu görülmüştür. Hatta gidilen kafe grup aidiyeti şeklinde tanımlanabilmekte ve kafe, bireyin hangi tanımlamaları içerdiği kadar içermediğini de vurgulamaktadır. $\mathrm{Bu}$ yüzden gençler kafeleri tercih ederken kendilerine yakıştırdıkları yerlere gittiklerini ve nasıl bir yere giderlerse o şekilde tanımlanacaklarını dile getirmişlerdir. Örneğin; bir öğrenci eğer kötü bir yere giderse tanımlanmasının de bu yönde olacağını (Görüşmeci 6, lise öğrencisi, erkek) bir başka öğrenci ise "Tercih ettiğim kafenin ortamı ben demektir” (Görüşmeci 9, lise öğrencisi, kız) derken kafenin ortamı ile birey tanımını özdeşleştirmektedirler. Nitekim gençlerin üzerinde durdukları bu tanımlama kafenin sembolik bir anlam ve sermaye çerçevesinde incelenmesine zemin oluşturmaktadır. 
Tercih edilen kafenin bireyi tanımlamasının yanında tercih edilmeyen kafelerin de aynı işleve sahip olduğu görülmektedir. Gidilen kafe nelerden hoşlanıldığını ifade ederken gidilmeyen kafeler de nelerden hoşlanılmadığını, bireylerin nelerden uzak durduklarını, neyi dışladıklarını da gösterebilmektedir. Bunu açıkça dile getiren bir öğrenci ise "Ergenlerin gittiği yere gitmiyorsam ben ergen değilim demektir mesela ve onların olduğu ortamlara da girmem gibi" (Görüşmeci 28, üniversite öğrencisi, kı) ifadeleriyle dışlama pratĭgi/öteki üzerinden kimliğini oluşturmakta ve kendisinin bir ergen olmadığını vurgulamaktadır. Diğer yandan; kafenin bireyi tanımlaması, bunun bilinçli bir tercih olmasından kaynaklanmaktadır. Bu yüzden kafenin bireyi tanımladığını düşünen öğrenciler, kafe seçerken oldukça dikkatli davranmaktadırlar. Seçimlerin zevkleri simgelediğini dile getiren öğrenciler, kafeyi zevk anlamında sembolleştirmektedirler. Bu bağlamda gençler için bilinçli bir tercihin yapılması, kafeyi tercih eden bireylerin birbirlerine benzediklerinin bir göstergesi olmaktadır.

Öğrencilerin gittikleri yerlerde farklı uygulamalar aracılı̆̆ıyla konumlarını arkadaşları ve çevreleri ile paylaşmaları, gidilen kafelerin nasıl yerler olduklarının önemini artırmaktadır. Örneğin; bir öğrenci "Her gittiğim yerde konum atıyorum ve o attığım konum benim etiketim, gittiğim kafeyi konum bildirilerime eklememse profilimi tanımlar" (Görüşmeci 11, lise öğrencisi, kız) diyerek gittiği yerlerde paylaşmış olduğu konumların bireyin statüsünü gösterdiğini belirtmektedir ki bu bireysel strateji ve kişisel çıkarlarla eşdeğerdir.

Liseli gençlere nazaran üniversiteli gençler için kafenin bireyi tanımladığı kanısı daha yaygındır. Kafe seçiminin bireyi tanımladı$\breve{g} 1$ Üniversite öğrencilerinin cevaplarında rahat ortam ile birey tanımı arasında bir ilişki olduğu belirtilmiştir. Örneğin; "Girdiğim ortamlar ve rahat ettiğim ortamlar bellidir. Buna uygun kafelere giderim. Gittiğim yer de benim neye yatkın olduğumu açıkça gösterir" (Görüşmeci 32, üniversite öğrencisi, erkek) diyen bir öğrenci, rahat olduğu yerlere giderken bireysel olarak neye yatkın olduğunu açıkça ifade ettiğini düşünmektedir. Yapılan tercihlerle kişiliğin ayrıntılarının dahi belirlenebileceğini vurgulayan bir öğrenci ise şu ifadeleri kullanmaktadır: "Tercih ettiğim kafe beni temsil eder, çok gürültülü bi yere gitmiyorsam sakinliği sevdiğim içindir ya da kafeye gelme amacım muhabbet olduğu 
içindir. Benim için muhabbetin müzikten ön planda olduğu anlamı ç1kar burdan" (Görüşmeci 29, üniversite öğrencisi, kı). Belirtildiği üzere tercih edilen kafe, bir profil temsilidir ve öğrenciler için değerlidir.

Üniversiteli gençlerin dile getirdikleri tercih, sahip olunan zevk ile bir ayrımın oluşturulduğunu da yansıtmaktadır. Seçenek ne kadar çok olursa tercih edilen yerin değeri artmakta ve bu değerle bireyin zevki simgelenmektedir. Konuyla ilgili bir öğrenci durumu şu şekilde açıklamıştır:

"Merkezde seçtiğim kafeler beni tanımlar ama evime yakın olan yerler için tanımlamaz. Zorunlu olduğum için oraları tercih ediyorum çünkü kafe pek yok evime yakın. Merkezde daha seçici olabiliyorum. Benim profilime, tercihlerime, zevklerime uygun yerlere gidebiliyorum. Seçenek çoksa kimin neyi seçtiği kişilik meselesi bile olabilir, seçim çok önemli” (Görüşmeci 35, üniversite öğrencisi, kız).

Lise öğrencilerinden farklı olarak üniversite öğrencilerinin dile getirdiği müdavimlik, bireyin kafe üzerinden kimlik oluşturduğuna ve onu kimliğinin bir parçası olarak gördüğüne işaret etmektedir. Öğrencilerin kafelerde 'benlik' şeyler bulmaları (Görüşmeci 40, üniversite öğrencisi, kız), kafeyi sahiplenip müdavimi olmalarını ve bu yerle kendilerini özdeşleştirdiklerini temsil etmektedir. Başka bir deyişle, tercih edilen kafe "sözlere dökmeden bireyi anlatmış" (Görüşmeci 25, üniversite öğrencisi, erkek) olmaktadır. Kafenin bireyi anlattığını düşünen gençler, gidilen kafeleri ve beraberinde yapılan konum paylaşımlarını kişiyi ele veren ipuçları olarak tanımlamaktadırlar. Bu bağlamda, kafe “facebooktaki profil gibi” (Görüşmeci 36, üniversite öğrencisi, kız) görülmekte ve bireyi yansıttığı düşünülmektedir.

\section{Kafe: Kültürel Bir Simge Olabilir}

Kafenin bireyi tanımladığı hususunda benzer kanıya sahip olan lise ve üniversite öğrencileri, kültürel simge hususunda farklı algılara sahiptirler. Bu bağlamda, kafenin kültürel bir simgeye dönüşmesinde eğitimin önemli bir etken olduğunu söyleyebiliriz.

Lise öğrencileri arasında kafenin kültürel altyapıyı simgelediğini düşünen öğrenciler, üniversite öğrencilerine oranla çok azdır. Kafenin kültürel bir simge olduğunu düşünen lise öğrencileri, kafe- 
ye giden bireylerin aynı profilde ve aynı kültürel seviyede olduklarını düşünmektedirler. Gençlerin anlatımlarına göre 'aynı kültüre sahip insanlar' benzer kafeleri tercih etmektedirler ve kültürel seviye ile bireyin tanımlanmasını eşdeğer bulduklarını dile getirmişlerdir. Kafenin bireyi tanımladığına çoğunlukla hemfikir olan lise öğrencileri, kafenin kültürel altyapıyı simgelemesi konusunda farklı görüşlere sahiptirler. Lise öğrencileri içerisinde kafenin kültürel altyapıyı simgelemediğini düşünen çoğunluğun çıkış noktası, kafelerin herkese açık yerler ve kafeye girişlerin denetlenemeyecek oluşudur. Bu bakış açısı, lise öğrencilerinin çoğunun kafe seçiminde seçici olmamasından da kaynaklanmaktadır. Nitekim bireyin kafeyi tanımladığı bağlamındaki sorulara lise öğrencilerinin verdiği cevaplar üniversite öğrencilerinin vermiş olduğu cevapların yanında yüzeysel kalmıştır.

Kültürel simge bağlamında sorulan soruya üniversite öğrencilerinin vermiş olduğu cevaplar ise bireyin tanımlanması ile paralellik göstermektedir. Üniversite öğrencileri için bireyin tanımlanması ile bireyin kültürel seviyesi bir bütündür. Gidilen kafenin bireyin kültürel seviyesini yansıttığını ve kafenin bu anlamda bir sembol olduğunu düşünen öğrencilerden biri bu durumu şu şekilde açıklamıştır:

"Mesela ben sosyal medyayı çok kullanan bir insanım ve kafeye giderken daha estetik, kültürel seviyeme uygun yerleri tercih ederim. Ama bir erkek sırf oyun için gittiği kafede buna uygun bir yere gider. Bir simge bence bu da ve aramızdaki kültürel uyuşmazlığı da gösterir"' (Görüşmeci 39, üniversite öğrencisi, kız).

Kafeye ne amaçla gidildiği ve buna dikkat edilmesi, kültürel bir simge olabilirken kültürel seviyenin birbirine yakın olması benzer kafeleri tercih etme sebebi olarak karşımıza çıkmaktadır. Aynı kafeyi tercih eden bireylere aynı şeyler cazip gelmekte ve bu da kültürel bir benzerlik oluşturmaktadır. Öğrencilerin sık sık dile getirdikleri kafede görsel olarak bulunan kitap tasarımı dahi kafeyi tercih etme sebebi, bir huzur aracı ve dolaylı olarak kültürel bir sembol olarak karşımıza çıkmaktadır. Soruyla ilgili olarak üniversite öğrencilerinin cevaplarının yoğunlaştığı bir diğer kategori de kafenin hedef kitlesidir. Öğrencilerden biri bunu şu şekilde ifade etmiştir: "Bence kültürel seviyesi benzer olan insanlar hemen hemen aynı kafeleri tercih ediyor, bu da hedef 
kitlesi ile alakalı. Kültürel açıdan benzer olanlar aynı kafelerin kitlelerini oluşturuyorlar" (Görüşmeci 38, üniversite öğrencisi, kız). Başka bir deyişle; kafedeki profil ile kültürel altyapı özdeştirilip kafeler buna göre kültürel simge olarak benimsenmekte ve genel profil öğrenildiği taktirde kafelerin müdavimi olunmaktadır.

Bunların aksini düşünen üniversite öğrencileri, lise öğrencilerine oranla az olmakla birlikte cevaplarında ortak noktalar da yer almaktadır. Tıpkı lise öğrencilerinde olduğu gibi üniversite öğrencilerinin bir kısmı da kafeye gelecek kişilerin tam olarak belirlenemeyeceğini bu sebeple de kültürel bir simge olarak ele alınamayacağını dile getirmiştir. Örneğin bir öğrenci kafeye gelen kişilerin her zaman aynı olmayacağını, gün içinde dahi farklı etkenlerle farklı kişileri barındırabileceğini düşünmektedir (Görüşmeci 21, üniversite öğrencisi, erkek). Kafenin herkese açık olan kamusal yerler olduğunu vurgulayan öğrenciler için kafeler, kültürel altyapıyı simgelememekte; her kafe birbiri ile benzer olarak algilanmaktadır.

Özetle, lise öğrencileri kafe seçiminde gösterişe bununla ilişkili statüsünü gösteren konum paylaşımına önem verirken üniversite öğrencileri kafelere kültürel seviyelerini yansıtması üzerinden değer atfetmektedir. Gençler arasındaki bu fark, sembolik sermaye kavramı ile birebir örtüşmektedir. Gençler eğitim seviyeleri artıkça bunun ayrımını belirtebilecek simgelere sahip yerleri tercih etmekte ve diğerlerinden ne kadar farklı olduklarını, neye değer verdiklerinin kültürleri ile paralel olduğunu vurgulamaktadırlar. Başka bir deyişle; sembolik sermaye ile birlikte toplumda farklı tercihlerin sahibi olduklarını sosyal sermayeleri ile desteklemektedirler.

\section{Gösteriş Belirtisi ve Kanıtlama Çabası}

Araştırmada genç nüfusun pahalı olmalarına rağmen bazı kafeleri yoğunlukla kullandıkları görülmüştür ve bu tarz kafeleri ne sebeple kullandıkları bize bu yerlere hangi değerleri atfettiklerini göstermektedir. Pahalı kafelerin neden tercih edildiği sorusuna lise öğrencilerinin verdikleri cevaplar içerisinde önemli payı 'gösteriş/popüler olma çabası' düşüncesi kapsamaktadır. Lise öğrencilerinin çoğu için pahalı kafeler gösteriş ile eşdeğerdir ve pahalı yerler gidenler popüler olmak için gitmektedirler. Bu bağlamda, lise öğrencilerinin çoğu için lüks kafelere 
gitmek popüler olmak için gerçekleştirilen bir eylemdir. Lüks kafelerin bireylerin olmadığı gibi görünmelerini sağladığını düşünen lise öğrencilerinin bir kısmı, bu durumun öğrencilerin harçlıklarını zarara uğrattığını düşünmektedirler.

Lise öğrencilerinin 'hangi kafede bulunursan etiketin daha düzgün gözükür' kapsamında belirttikleri görüşler, bize kafelerin bireyleri etiketlemek için önemli yerler olduğunu göstermektedir. Kafede konumların bildirilmesi, o kafede olduğunu belirtecek şekilde fotoğrafların çekilmesi bir statü ve kendisini diğerlerinden ayırmanın bir belirtisi olarak karşımıza çıkmaktadır. Lise öğrencilerinin aktardıklarına göre; kafeyi tercih eden bireyler yüksek statüde olmasalar bile yüksek statüdeymiş gibi görünmek istediklerini ve bu şekilde göründükleri takdirde mutlu olacaklarını düşünmektedirler. Bir öğrenci, konum bildirimi üzerinde durarak konuyu şu şekilde açıklamaktadır:

"Pahalı kafeye gitmek onu tercih etmek tamamen bi şekil yarış1dır. Eğer buralara gidip check-in yaparsan benim şeklim düzgün havalıyım ve zenginim demektir. Şeklini düzgün göstermek için de gidiyorlar buralara ama gereksiz yere para ödemekten başka bi işe yaramıyor o pahalı yerler" (Görüşmeci 6, lise öğrencisi, erkek).

Sosyal medyada her şeyin paylaşılması bireylerin nerede bulunduklarını önemli hale getirmiş̧ir. Lise öğrencileri konumun bir etiket olduğunu, iyi ve pahalı yerlerde konum paylaşıldığında bireyin popüler ve gösterişli olduğunu aksi halde sıradan olarak tanımlandığını dile getirmişlerdir. Öğrenciler için bireylerin konumun iyi olmasına önem vermesi, onların pahalı yerlere gitmelerine sebep olmaktadır. Öte yandan lise öğrencileri arasında pahalı bir kafeye gitme sıklığı, amacı temsil eden bir eylem olarak benimsenmektedir. Örneğin; bir öğrenci “...O yeri de görmek, tanımak, nasıl bi yer olduğunu keşfetmek için gidiyorlar. Biz de bazen gidiyoruz ama bu sık yapılan bi şey değil. Sık yapıyorsa popüler olmak için yapıyordur" (Görüşmeci 1, lise öğrencisi, erkek) ifadeleri ile yerin anlamsal farklılığını kafeye gitme sıklığına bağlamıştır. Lüks kafelere gidilebilir; ancak sadece tanımak, görmek için nadiren gidilebilir. Bundan farklı bir amaca büründüğü ve pahalı kafeye devamlı gidildiği zaman eylem, anlam değişikliğine uğramakta ve popüler olma çabasını simgelemektedir. 
Buna karşılık, lise öğrencileri arasında pahalı kafelere gitmeyi olumlu bulan ve kendilerinin de aynı eylemde bulunduğunu dile getiren öğrenciler de vardır. Olumlu bakış açısına sahip olan öğrencilerin bir kısmı sebep olarak pahalı yerlerin daha rahat bir ortam sunmas1$\mathrm{n} 1$ ileri sürmüşlerdir. Örneğin; bir öğrenci ortamın rahat olmasını şu şekilde aktarmıştır: "Harçlık sıkıntım olsa da o tarz yerlere giderim çünkü ucuz yerlerde fena tipler var. Rahat rahat oturamıyorsun, giyinemiyorsun. Lüks yerler bu rahatlığı veriyor çünkü seçilmiş insanlar, durumu daha iyi olanlar geliyor oralara" (Görüşmeci 10, lise öğrencisi, kız). Öğrencinin de belirttiği üzere pahalı olan yerler 'iyi' olanı simgelemektedir ve öğrenci bu tanımlaması ile bir dışlama pratiği sergilemektedir. Bu durum, üçüncü yerlerin herkese açık olduğu düşünülen özelliğinin değiştiğini göstermekte ve kimi kafelerde 'herkes gelemez bazı insanlar gelebilir' anlamının benimsendiğini yansıtmaktadır.

Pahalı kafelerin diğer kafelere göre farklı bir içeriğe sahip olmas1, diğer kafelere nazaran neden tercih edildiğine de bir sebeptir. $\mathrm{Bu}$ tarz kafelerin sessiz sakin kafeler olmasının yanı sıra elitliği temsil etmesi görece olumlu değerler atfedildiğini göstermektedir. Örneğin; bir ögrenci "Pahalı kafeler daha rahat bir ortam sunuyor ve bu bence elitlikle alakalı bir şey. Sonuçta lüks yerler daha elit ve herkes oraya kolay kolay gelemiyor, rahat insanlar geliyor. Ortamı da daha elit oluyor" (Görüşmeci 20, lise öğrencisi, kız) sözlerine yer vermiş ve kafenin elitliğini herkesin kafeye gelememesine bağlamıştır. Kafeye herkesin gelememesini iyi olmayanların dışarıda kalması olarak algılayan kimi gençler, bunu kafenin kötü olandan arınması/sterilize olması şeklinde ele almaktadırlar. Bunun yanı sıra, kafeye gitmek bir zevk/ beğeni sunmak, hayattan daha fazla zevk almak ile eşdeğer tutulmakta ve bu yüzden gidilen yerler özenle seçilmektedir.

Lise öğrencilerinin cevaplarından anlaşıldığ 1 üzere pahalı kafeler ve onları tercih eden bireyler, çoğunlukla negatif bir etikete sahiptir ve bazıları gittikleri kafe ile statüsünün iyi olduğunu göstermeye çalışmaktadır. Görüşmelerde aktarılanlarla üçüncü yerlerin bireylerin yaşam tarzlarını yeniden yükleyebilmelerine imkân sağlayan yerler olabildiği görülmektedir. Bunun aksine pahalı kafelere gitmeyi olumlu karşılayan öğrencilerin ileri sürdükleri sebepler, sembolik sermayenin emarelerini barındırmaktadır. Gidilen kafe bireyin diğerlerinden özel 
olarak ayrıldığını vurgulamaktadır. Bu ayrıma dikkat çekmek için de kentteki mekânsal ayrışmaya sembol olan lüks kafeler tercih edilmekte ve kafe diğerleri ile aralarındaki ayrımı açıça gösteren sembolik bir değere dönüşmektedir.

Pahalı kafelerin neden tercih edildiği sorusuna üniversite öğrencilerinin verdikleri cevaplarda pahalı kafelere ve orayı tercih eden bireylere karşı genel anlamda olumsuz bir tutumun oluştuğu görülmektedir. Kafenin ucuz ve kaliteli olmasına yoğunlaşan üniversite öğrencileri, pahalı kafelere gitmeyi gösteriş, gereksiz ve harçlıklarının boşa gitmesi olarak görmektedirler ve bu algıya vurgu yapılmasındaki en önemli etken, sosyal medyada kimlik üretilmesinden kaynaklanmaktadır. Akıllı telefonların yaygınlaşması ve uygulamaların daha çok kullanılması beraberinde sosyal kimliğin önem kazanmasına ve konum paylaşırken bulunulan yere dikkat edilmesine yol açmıştır.

Üniversite öğrencilerine göre toplumdaki gösteriş merakl11 l̆ğ kafe seçimine de yansımaktadır ve bireylerin konum bildirirken buna önem verdiklerini vurgulanmaktadır. Nitekim kafe seçiminde paha11 kafeler tercih edilirken o yerin diğer yerlere göre daha elit olması üzerinde durulmakta ve gidilen kafe, kimliği yeniden üretirken birey öncekine göre daha yüksek bir statünün sahibi olmaktadır. Üniversite öğrencilerinin üzerinde durduğu bir diğer husus da pahalı kafelere gidilerek bireylerin kendilerini kanıtlama çabası içerisine girmeleri ile ilgilidir. Öğrencilerden biri pahalı kafelere gitmenin zorunlu olmadığı halde etrafa kendini ispatlamak için gidildiğini şu şekilde ifade etmiştir: "Pahalı kafelere gitmek bence tamamen el âleme kendini kanıtlama çabası. Çevredekiler beni o yerde görsün, tanımlasın, benim yüksek bir insan olduğumu kabul etsin diyerek gidiyor. Bu yüzden özentilik içeriyor benim için" (Görüşmeci 25, üniversite öğrencisi, erkek). Pahal1 kafeye gitmenin "kademe atlama/gidince yüksek statüden olduğunu gösterme" (Görüşmeci 35, üniversite öğrencisi, kız) amacına sahip olması, üniversite öğrencileri arasında hâkim olan düşüncedir. Kimilerinin kafeye giderek kendilerini orada etiketlenmeye ihtiyaç duyduklar1nı belirten öğrenciler, yükselen gösteriş topluluğunun bireylerin olmayan kimlikler üretmesine neden olduğunu düşünmekte ve bu durumun öğrencilere zarar verdiği üzerinde durmaktadırlar. 
Bunlara karşın üniversite öğrencileri arasında pahalı kafeye olumlu değer atfeden ve pahalı kafenin ucuz kafelere göre daha rahat olduğundan bahseden bir öğrenci, tercih sebebini sadece rahatllğga dayandırmamakta aynı zamanda da pahalı kafe ile gelen zevk/beğeni ayrışmasını vurgulanmaktadır. Öğrenci konuyla ilgili görüşlerini şu şekilde ifade etmiştir:

"Ben de pahalı kafelere gidenlerdenim. Eğer kafenin ortamı kendimi rahat edebileceğim düzeydeyse fiyatının önemi yoktur benim için. Önemli olan zevkime uygun bir kafede arkadaşlarımla sohbet muhabbet etmektir. Bu dışarıdan gösteriş meraklılığı olarak gözükebilir ama değil tamamen zevk, beğeni ve rahatlık seçimi. Ucuz yerlerde beğenime açı yerlerin olmamasıdır bunun sebebi" (Görüşmeci 38, üniversite öğrencisi, kız).

Burada öğrencinin bahsettiği zevk/beğeni, ucuz yerlerde karşılığının bulunamadığı ya da bulunamayacağı bir zevk/beğeni şeklinde tanımlanmakta ve beğeninin farklı eylemlere dökülmesi ayrımı somutlaştıran, sembolik karşılığı olan bir durum olarak karşımıza çıkmaktadir.

Sonuç olarak, katılımcıların da aktardığı üzere pahalı olduğu düşünülen kafeler, gösteriş ve kendini kanıtlamak için gidilen yerler olarak görülmektedir. Bu bağlamda, kimi üçüncü yerlerde nötr ve eşitlikçi olma özelliği toplumun yapısı ile değişikliğe uğramış; artı üçüncü yerlerden biri olan kafe, yeni kimliklerin oluşması için bir basamak halini almış ya da kimlik farkının altını çizmek için beğenilerin somutlaştığ1, mekânsal ayrıma yol açtığı sembolik sermayeye dönüşmüştür.

\section{Sonuç}

Kafeleri üçüncü yerler, sosyal ve sembolik sermaye bağlamında incelemeyi amaçlayan bu araştırma üçüncü yerlerin gençler tarafından sosyal ve sembolik sermaye aracı olarak kullanıldığını, gençlerin gündelik yaşamda tercih ettikleri yerlere göre tanımlandığını ve mekânların zamanla farklı anlamlara ev sahipliği yaptığını savlamakta ve teknoloji ile birlikte mekânın kullanımının da değiştiğini ileri sürmektedir.

Sosyal bilimler alanında yeni bir kavram olan üçüncü yerler, Oldenburg'un kazandırdığı bir kavram olup yaratıcı etkileşimleri 
mümkün k1lan topluluk hayatının sabitleyicileridir (1991). Ev ve iş yerleri dışında kalan ve insanların buluşma, sosyalleşme, eğlenme gibi amaçlarla kullandıkları yerler şeklinde tanımlanan üçüncü yerler; nötr, eşitlikçi, temel aktivitesi sohbet olan, herkesin kolaylıkla ulaşabileceği, müdavimleri olan, sade bir profili içeren yerlerdir. Fakat teorisyenin değinmediği noktalar da mevcuttur. Bunlar kafelerin eşitlikçi olmayan yerler olabildiği, kimi zaman temel aktivitenin internet kullanımı olabildiği ve sade bir üçüncü yer yerine melez bir üçüncü yer olabildiğidir. Zamanla kafelere gelen internet hizmeti, bu yerlerin kullanımında değişikliğe sebep olmuş ve wi-fi özelliği ile sosyal yaşamı büyük oranda etkilemiştir. Bugün üçüncü yerlerden biri olan kafede, iletişim kurmanın yolları değişmiş̧; bazı gençler için sosyal bağlar, internet bağlantısı ile zayıflamaktayken bazıları için kullanılan konum uygulamaları ile sosyalleşme artmıştır. Fakat kafe içinde internet kullanımının artması ile karşılıklı iletişim tehdit altındadır. Ayrıca internet hizmeti veren kafeler, internet için tercih edilen bir yer halini almıştır. Özellikle konum bildirerek kafenin bir etiket aracı olarak algılanmaya başlanması, kafenin gündelik yaşamdaki işlevini de değiştirmiştir.

Diğer taraftan, Mikunda'nın üçüncü yerler hakkında ileri sürdükleri günümüzle uyum içerisindedir. Ona göre; üçüncü yerler ticari olmayan kamusal alanlar değildirler ve bu yüzden görselliği ve gösterişi ile dikkat çekerler (2011). Ayrıca teorisyen, üçüncü yerlerin insanların yaşam tarzlarını yeniden yükleyebilmelerine imkân sağlayan yerler olabildiğini öne sürer. Kafelerin bugünkü durumu göz önünde bulundurulduğunda; Mikunda'nın ileri sürdüklerinin geçerliliğini koruduğu görülmektedir. Kimi zaman bir gösteriş yeri olarak dikkat çeken kafeler, gündelik yaşamda bireylerin kimliklerinin ve yaşam tarzlarının yeniden üretildiği yerler olarak karşımıza çıkmaktadır.

Kafeler her ne kadar kamusal alan olup herkese açık olarak tanımlansa da barındırdığg modernlik imgesi ile markalaşma ve tüketim kültürünün odağında yer almaktadır. Bu yüzden de kafeler, tabaka11 toplumsal yapının yeni simgesel göstergeleri olmuş, gidilen kafe mekânın tüketilmesi ile kimliğin üretilmesini içerir hale gelmiş ve toplumdaki statü ayrımının gözle görülür hale geldiği üçüncü yerlerden birine dönüşmüştür. Ayrıca kafelerin zevk ve beğenilere göre tercih edilmesi, statüyle ilişkili bir ayrımı simgeleyerek kültürel tarzların 
zeminini oluşturmaktadır. Bu bağlamda kafeler, Bourdieu'nün sözünü ettiği sembolik ve sosyal sermayeyi içeren yerler olup toplumsal aktörlerin grup aidiyetleri, sosyal ve kültürel kodları bir yönü ile sosyal hayatı kolaylaştırırken bir yönü ile de sosyal eşitsizlikleri meydana getiren bir fonksiyona sahip olmuştur. Diğer yandan, kafelerin kültürel altyapının göstergesi olarak düşünülmesi kafeyi tercih eden bireyler tarafından etiketleme ve dışlama pratiklerinin yaygınlaşması bağlamında bir tehdit oluşturmaktadır. Nitekim belli bir kesimin kafeye girmesini engellemeye çalışmak ya da bunun olması gerektiğini düşünmek gençlerin dışlama pratiğini benimsediğini göstermektedir.

Sonuç olarak, gençlerin hangi mekânlarda ne kadar vakit geçirdikleri onların yaşam tarzlarına, sosyal ve sembolik sermayelerine dair izler barındırmakta, mekân içinde ne yaptıkları ise mekânsal pratiklerin ve kodların çözümlemesini yapmayı sağlamaktadır. Yer, ilişki ağı ve kültürel yapı arasında yakın ve kaçınılmaz bir ilişkinin olduğu kafeler; internetin etkisi ile farklı kullanımlara ve anlamlara ev sahipliği yaparak melez bir üçüncü yer haline gelmiştir. 


\section{Kaynakça}

Bourdieu, P. (2007). Düşünümsel Bir Antropoloji İçin Cevaplar. (Çev. N. Öktem), İstanbul: İletişim Yayınları.

Carr, A. (2010). Third Place Discourse. Kansas State University.

Crick, A. P. (2011). Rethinking Oldenburg: Third Places and Generation $\mathrm{Y}$ in a Developing Country Context. International CHRIE Conference, 1-22.

Çağlayan, S. (2012). Anadolu'nun İlk Kamusal Mekânı: Kahvehane. Muğla Sitkı Koçman Üniversitesi Sosyal Bilimler Enstitüsü Dergisi, Sayı 29, 95-110.

Memarovic, N., Fels, S., Anacleto, J., Calderon, R., Gobbo, F. and Carroll, J. M. (2013). Rethinking Third Places: Contemporary Design With Technology. Workshop on Human Computer Interaction for Third Places, 1-16.

Oldenburg, R. (1991). The Great Good Place. New York: Marlowe and Company.

Rosenbaum, M. S., Sweeney, J. C. and Windhorst, C. (2009). The Restorative Qualities of an Activity-Based, Third Place Café for Seniors: Restoration, Social Support, and Place Attachment at Mather's-More Than a Café. Seniors Housing \& Care Journal, Vol 17, 39-54.

Sami, K. (2010). Halk Kültürü Bağlamında Kahvehanelerin Toplumsal ve Mekânsal Dönüşümleri Diyarbakır Kent Örneği. Millî Folklor Dergisi, Say1 85, 159-172.

Ulusoy, K. (2011). Türk Toplum Hayatında Yaşatılan Kahve ve Kahvehane Kültürü. Millî Folklor Dergisi, Say1 89, 159-169.

Waxman, L. (2006). The Coffee Shop: Social and Physical Factors Influencing Place Attachment. Journal of Interior Design, Say1 3, 35-53.

Woldoff, R. A., Lozzi, D. M. and Dilks, L. M. (2013). The Social Transformation of Coffee Houses: The Emergence of Chain Establishments and the Private Nature of Usage. International Journal of Social Science Studies, Vol.1, No. 2; 205-218.

Yağbasan, M. ve Ustakara, F. (2008). Türk Toplumunda Kahvehane ve Kafelerdeki İletişimsel Ortamı Belirlemeye Yönelik Bir Alan Araştırması. Fırat Üniversitesi Sosyal Bilimler Dergisi, Cilt: 18, Say1: 1, 233-260. 